\title{
VALIDITAS LKPD FISIKA SMA MENGGUNAKAN MODEL PROBLEM BASED LEARNINGBERBASIS TEKNOLOGI DIGITAL
}

\author{
Riti Desmiwati ${ }^{1)}$, Ratnawulan ${ }^{2)}$, Yulkifli ${ }^{2)}$ \\ ${ }^{1)}$ Mahasiswa Magister Pendidikan Fisika Universitas Negeri Padang \\ email: desmiwatiriti@gmail.com \\ ${ }^{2)}$ Dosen Magister Pendidikan Fisika Universitas Negeri Padang
}

\begin{abstract}
One effort that can be done by teachers to improve the competence of students was to develop of Student Worksheet (LKPD). LKPD was said to be qualified if it has valid criteria. Valid means the developed product can be used to measure what should be measured. Validity of LKPD was assessed by experts in the field. The purpose of this study was to determine the validity of LKPD experimentphysics oriented by problem based learning models be used tools practicum based on digital technology. The methode of this study was descrptive methode. The research instrument used was validation sheet in the form of assessment questionnaire. Analysis of data used descriptive analysis. The validation result was obtained LKPD physics experiment oriented Problem Based Learning model with tools of practicum based on digital technology was valid criteria.
\end{abstract}

Keyword: Problem Based Learning, Digital Technology, Student Worksheet

\section{PENDAHULUAN}

Sebelum melaksanakan pembelajaran, setiap pendidik dituntut untuk dapat mempersiapkan segala sesuatu yang berhubungan dengan kelangsungan pembelajaran(Abidin: 2014). Salah satu persiapan yang harus dipersiapkan pendidik adalah bahan ajar.Dalam hali ini, bahan ajar yang dipilih adalah Lembar Kerja Peserta didik (LKPD).Pemilihan LKPD ini didasarkan pada pendapat Tim Instruktur Pemantapan Kerja Guru (PKG) dalam Sudiati (2013) yang menjelaskan bahwa "salah satu cara membuat peserta didik aktif dalam pembelajaran adalah dengan menggunakan LKPD.

LKPD merupakanlembaran-lembaran berisi tugas yang harus dikerjakan peserta didik selama pembelajaran berlangsung (Majid, 2006). Tugastugas yang diberikan dalam LKPD dapat berupa tugas teoritis dan atau tugas praktis.Dalam pelaksanaannya, LKPD dapat dibagi ke dalam dua kelompok, yaitu LKPD eksperimen dan LKPD non-eksperimen. LKPD eksperimen adalah LKPD yang digunakan untuk membimbing peserta didik dalam melakukan kegiatan praktikum dan menemukan konsep dalam kerja ilmiah.Sedangkan LKPD non eksperimen adalah LKPD yang digunakan untuk membimbing peserta didik dalam memahami dan mengomunikasikan suatu konsep dalam bentuk diskusi/tanya jawab (Depdiknas, 2008).

Berdasarkan pengelompokkan LKPD tersebut, maka LKPD yang dikembangkan dalam penelitian ini adalah LKPD eksperimen. Untuk meningkatkan keefektifan dan keefisianan pelaksanaan praktikum, maka LKPD yang dikembangkan berbantukan alat praktikum berbasis teknologi digitalYulkifli (2016). Dalam hal ini, alat praktikum yang masih bersifat manual dimodifikasi menjadi alat praktikum berbasis sensor dan teknologi digital.Yulkifli (2014) menjelaskan bahwa, kemajuan teknologi sensor dan digital membuka peluang pembuatan alat-alat praktikum dan pengukuran yang lebih efektif dan efisien dalam penggunaannya sehingga tujuan dan hasil yang diharapkan dapat lebih optimal.

Berdasarkan observasi terhadap LKPD yang digunakan di sekolah, diketahui bahwa LKPD belum sesuai dengan harapan dan format yang berlaku, dengan indikator: (1) belum terdapat petunjuk belajar, (2) belum ada informasi pendukung untuk meningkatkan rasa ingin tahu peserta didik, (3) kompetensi pembelajaran yang dicapai lebih terfokus pada aspek pengetahuan, (4) lembar kegiatan belum sesuai dengan pendekatan saintifik, (5) alat ang digunakan dalam praktikum masih bersifat manual dan sulit digunakan. Selain itu, melalui wawancara dengan peserta didik diketahui bahwa 80\% mereka menyatakan bahwa LKPD yang ada di sekolah belum menarik, sulit dipahami dan hanya dipenuhi oleh latihan-latihan yang bersifat teoritik. 
Oleh karena itu, untuk meminimalisir beberapa permasalahan tersbut, maka upaya yang dapat dilakukan di antaranya adalah mengembangkan LKPD sesuai dengan struktur dan format yang telah ditentukan, mendesain LKPD semenarik mungkin serta memiliki tingkat kejelasan yang tinggi sehingga mudah dipahami oleh peserta didik.

Agar penggunaan LKPD dalam pembelajaran dapat meningkatkan kompetensi peserta didik, maka LKPD yang yang dikembangkan adalah LKPD yang berkualitas. Salah satu kriteria LKPD berkualitas adalah LKPD memiliki tingkat kevalidan atau validitas yang tinggi.Kata valid sering diartikan dengan tepat, benar, sahih dan absah. Menurut Sugiyono (2010) valid berarti produk yang dikembangkan dapat digunakan untuk mengukur apa yang seharusnya diukur. Untuk mengetahui tingkat kevalidan suatu produk yang dikembangkan, maka dilakukan validasi. Asyar (2011) menyatakan bahwa validasi adalah proses permintaan persetujuan atau pengesahan terhadap kesesuaian produk dengan kebutuhan sehingga produk dinyatakan cocok dan layak digunakan dalam pembelajaran.

Validasi (kesahihan) adalah kualitas yang menunjukkan hubungan antara suatu pengukuran (diagnosis) dengan arti atau tujuan kriteria belajar (Ngalim: 2004). Uji validitas dilakukan oleh tenaga ahli.Menurut Sugiyono (2009) validitas produk dapat dilakukan oleh beberapa pakar atau tenaga ahli yang sudah berpengalaman untuk menilai kelemahan dan kekuatan produk yang dihasilkan. Depdiknas (2008) komponen yang dinilai ketika melakukan validasi mencakup beberapa komponen, yaitu: (1) Komponen kelayakan isi, mencakup kesesuaian SK dengan KD, kebutuhan, kebenaran substansi, manfaat, nilai moral dan nilai sosial. (2) Komponen penyajian (construct), mencakup kejelasan tujuan yang ingin dicapai, urutan penyajian, pemberian motivasi, daya tarik, interaksi (pemberian stimulus dan respon) dan kelengkapan informasi, penggunaan font (jenis dan ukuran huruf), lay out (tata letak), ilustrasi gambar, foto, dan desain tampilan. (3) Komponen kebahasaan, mencakup keterbatasan, kejelasan informasi, kesesuaian dengan kaidah bahasa Indonesia, penggunaan bahasa secara efektif dan efisien.

Selain itu, validasi juga dilakukan terhadap alat praktikum digital yang dikembangkan. Komponen untuk memvalidasi alat dapat dilihat berdasarkan 4 aspek (1) tujuan, (2) teknik pengoperasian, (3) ketepatan penggunaan dan (4) prinsip kerja. Menurut Samaun (1989) karakteristik yang perlu diperhatikan adalah : (1) Ketelitian (accuracy) sistem pengukuran dilakukan dengan membandingkan hasil pengukuran sistem dengan perhitungan secara teoritis, kemudian dilakukan pengukuran berulang dan memasukkan data ke dalam tabel serta menyelidiki ketelitian dari sistem alat ukur.

(3) Ketepatan adalah nilai atau hasil pengukuran yang mendekati nilai hasil pengukuran alat standar atau perhitungan secara teoritis. (3) Kesalahan (Eror) sebagai selisih dari harga pengukuran yang dihasilkan dengan harga sejatinya, dimana harga sejati adalah variable rata-rata dari sejumlah pengukuran yang tak terbatas dan akan selalu berubah tergantung pada semua aspek yang mempengaruhinya.

Berdasarkan uraian di atas, maka peneliti melakukan pengembangan LKPD Fisika berpraktikum menggunakan model PBL berbasis teknologi digital.Tujuan penelitian ini adalah untuk mengetahui tingkat kevalidan LKPD yang dikembangkan.

\section{METODE PENELITIAN}

Jenis penelitian ini adalah penelitan deskriptif untuk mengetahui tingkat kevalidan produk yang dikembangkan. Responden pada penelitian ini terdiri atas: dua rekan peneliti yang akan memberikan kontribusi pada tahapanself evaluationdan lima orang ahli yang terdiri atas 3 orang dosen Fisika Universitas Negeri Padang (UNP) dan 2 orang guru fisika kelas X MIA MAN Koto Baru solok pada tahap expert judgment.

Instrumen pengumpulan data validitas terdiri atas lembar self evaluationdan lembar validasi berupa angket.Analisis validitas menggunakan teknik persentase. Untuk mengetahui tingkat validitas LKPD digunakan kategori validitas. Menurut Riduwan (2009), suatu produk dikatakan valid apabila capaian responden lebih dari $60 \%$.

Validasi juga dilakukan secara empiris pada alat praktikum digital yang dikembangkan. Hal ini bertujuan untuk melihat tingkat ketepatan dan ketelitian alat. Ketepatan diketahui dengan membandingkan hasil pengukuran dengan prinsip/teori. Sedangkan ketelitian dilakukan dengan melakukan pengukuran secara berulang. Sementara itu, teknik analisis data validitas yang dilakukan adalah statistik deskriptif 


\section{HASIL DAN PEMBAHASAN}

\section{Hasil Penelitian}

Sebelum memvalidasi LKPD, terlebih dahulu dilakukan validasi terhadap instrumen penilaian validasinya. Penilaian instrumen validasimemiliki indikator yaitu petunjuk pengisian dalam lembar validasi jelas dan mudah dipahami, menggunakan Bahasa Indonesia sederhana dan jelas, pernyataan-pernyataan yang dibuatpada lembar validasi sesuai dengan tujuan yang ingin dicapai yaitu mengetahui validitas Lembar Kegiatan Peserta Didik (LKPD) berbasis model Problem Based Learning (PBL) dan alat praktikum berbasis teknologi digital,pernyataanpernyataan yang dibuat pada lembar validasi sesuai dengan indicatorpenilaian, pernyataan dalam lembar validasi tidak mengandung makna ganda,dan lembar validasi menggunakan format penilaian yang sederhana dan mudah dipahami. Hasil penilaian instrumen validasi dapat dilihat pada Tabel 1.

\begin{tabular}{|c|c|c|}
\hline No & $\begin{array}{l}\text { Instrumen yang } \\
\text { divalidasi }\end{array}$ & $\begin{array}{c}\text { Rata- } \\
\text { rata }\end{array}$ \\
\hline 1 & $\begin{array}{l}\text { Instrumen } \\
\text { LKPD }\end{array}$ & 100 \\
\hline 2 & $\begin{array}{l}\text { Instrumen Validasi } \\
\text { lembar penilaian }\end{array}$ & 99,11 \\
\hline 3 & Instrumen validasi alat & 91,67 \\
\hline 4 & $\begin{array}{l}\text { Instrumen } \\
\text { evaluation }\end{array}$ & 97,91 \\
\hline 5 & $\begin{array}{l}\text { Instrumen one to one } \\
\text { evaluation }\end{array}$ & 96,87 \\
\hline
\end{tabular}

Berdasarkan Tabel 1 diketahi bahwa semua instrumen validitas memiliki rata-rata > 80, yang berarti bahwa instrumen tersebut tergolong pada kategori sangat valid.Halini berarti bahwa angket validasi yang digunakan dalam menilaiLKPD sudah mengandung seluruh komponen yang dibutuhkan.

Setelah diketahui bahwa instrument validasi memiliki kriteria sangat valid, barulah selanjutnya dilakukan validasi terhadap LKPD menggunakan instrument tersebut. Validasi LKPD diawali dengan tahapan self evaluation yang dilakukan oleh 2 rekan peneliti yang juga mengembangkan LKPD berbasis teknologi digital. Self evaluationini dilakukan terhadap 3 aspek, yaitu aspek isi, struktur dan bahasa.Hasil evaluasi terlihat pada Tabel 2.
Tabel 2. Hasil Self Evaluation

\begin{tabular}{|c|c|c|}
\hline $\begin{array}{c}\text { Aspek } \\
\text { yang } \\
\text { Dievaluasi } \\
\end{array}$ & $\begin{array}{c}\text { Sebelum } \\
\text { Revisi }\end{array}$ & Setelah Revisi \\
\hline Aspek Isi & $\begin{array}{l}\text { Beberapa } \\
\text { kegiatan } \\
\text { pembelajaran } \\
\text { belum } \\
\text { rinci/jelas }\end{array}$ & $\begin{array}{l}\text { Kegiatan } \\
\text { pembelajaran } \\
\text { sudah } \\
\text { diperjelas }\end{array}$ \\
\hline $\begin{array}{l}\text { Aspek } \\
\text { Format }\end{array}$ & $\begin{array}{l}\text { Ukuran } \\
\text { huruf terlalu } \\
\text { kecil }\end{array}$ & $\begin{array}{l}\text { Ukuran huruf } \\
\text { diperbesar } \\
\text { sehingga } \\
\text { terlihat lebih } \\
\text { jelas }\end{array}$ \\
\hline $\begin{array}{l}\text { Aspek } \\
\text { Bahasa }\end{array}$ & $\begin{array}{l}\text { Beberapa } \\
\text { kalimat sulit } \\
\text { dipahami }\end{array}$ & $\begin{array}{l}\text { Bahasa } \\
\text { disederhanakan } \\
\text { sehingga } \\
\text { mudah } \\
\text { dipahami }\end{array}$ \\
\hline
\end{tabular}

Berdasarkan Tabel 2, diketahui bahwa LKPD yang dirancang harus direvisi lagi sebelum dilanjutkan pada tahap berikutnya. Baik dari aspek isi, format dan bahasa.

Setelah self evaluationdan revisi dilakukan, langkah selanjutnya adalah validasi oleh ahli (expert review). Selama proses validasi, validator memberikan masukan terhadap produk yang dirancang. Masukan tersebut sangat berguna bagi penulis dalam menciptakan LKPD fisika yang valid.Hasil revisi LKPD dapat dilihat pada Tabel 3.

Tabel 3 Hasil Revisi Validator

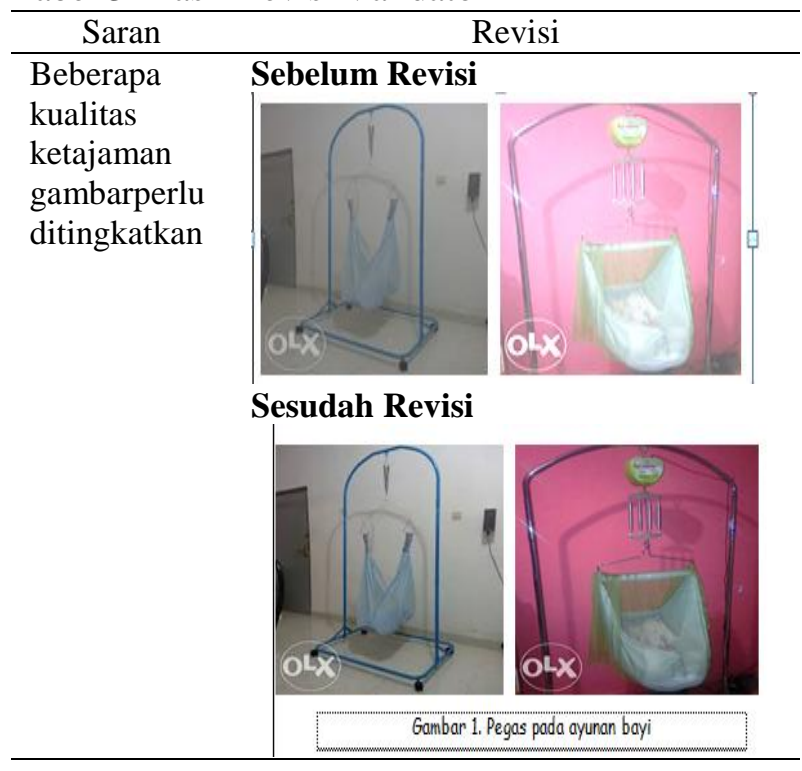




\begin{tabular}{ll}
\hline \multicolumn{1}{c}{ Saran } & \multicolumn{1}{c}{ Revisi } \\
\hline Gambar & Sebelum revisi \\
belum \\
dilengkapi \\
dengan \\
sumber
\end{tabular}

Berdasarkan tahap perancangan dan revisi yang dilakukan pada Tabel 3, selanjutnya LKPD Fisika berpraktikum berorientasi model PBL berbantukan alat praktikum teknologi digital dikembangkan dengan menganalisis hasil validasi dari validator.secara keseluruhan, validasi dilakukan terhadap 3 aspek. Selengkapnya dapat dilihat pada Tabel 4.

Tabel 4. Hasil validasi LKPD oleh Pakar

\begin{tabular}{llccccc}
\hline No & Aspek & \multicolumn{4}{c}{ Hasil Penilaian } & Rata \\
& Validasi & \multicolumn{4}{c}{ validator (\%) } & -rata \\
& LKPD & 1 & 2 & 3 & 4 & \\
& & RA & YH & HF & NL & \\
1 & Isi & 88,9 & 100 & 94,4 & 94,4 & 98,21 \\
2 & Konstruk & 94,4 & 91,7 & 91,7 & 100 & 94,45 \\
3 & Bahasa & 89,3 & 100 & 92,8 & 100 & 95,50 \\
\multicolumn{7}{l}{ Rata-rata Keseluruhan } \\
\end{tabular}

Berdasarkan Tabel 4diketahi bahwa semua aspek LKPD yang divalidasi memiliki rata-rata > 80, yang berarti bahwa LKPD yang dikembangkan sangat valid.

Setelah didapatkan LKPD dengan kriteria sangat valid, selanjutnya dilakukan validasi terhadap alat digital yang dikembangkan. Validasi alat dilakukan dengan dua cara, yaitu validasi dengan menggunakan angket validasi oleh validator dan validasi empiris melalui perhitungan matematis. Pertama, validasi dengan keusioner/angket yang dilakukan oleh validator ZK. Aspek yang divalidasi terdiri atas tujuan, teknik pengoperasian, ketepatan penggunaan dan prinsip kerjanya. Secara eksplisit, hasil validasi alat ini dapat dilihat pada Tabel 5.

\begin{tabular}{|c|c|c|}
\hline No & Aspek yang divalidasi & Skor \\
\hline 1 & Tujuan & 87,5 \\
\hline 2 & TeknikPengoperasian & 91,7 \\
\hline 3 & Ketepatan Penggunaan & 91,7 \\
\hline 4 & Prinsip Kerja & 87,5 \\
\hline \multicolumn{2}{|c|}{ Rata-rata } & 89,6 \\
\hline
\end{tabular}

Berdasarkan Tabel 5, terlihat bahwa hasil validasi memiliki rata-rata $>80$, yang berarti bahwa alat praktikum GHS berbasis teknologi digital yang dikembangkan sangat valid.

Kedua, validasi melalui pengukuran empiris. Validasi ini bertujuan untuk mengetahui tingkat ketepatan dan ketelitian alat. (1) Ketepatan. ketepatan pengukuran ditentukan dengan membandingkandata hasil pengukuran sistem dengan perhitungan secara teori.Besaran fisika yang disorot di sini adalah periode (T). Karena tujuan pembelajaran dari sub materi GHS yang diharapkan adalah peserta didik dapat menentukan besarnya periode GHS dari pegas yang disusun tunggal, seri dan paralel, maka ketepatan pengukuran pun juga dilakukan pada 3 
variasi susunan tersebut. Secara eksplisit, hasil dari ketepatan alat ini terlihat pada Gambar 1,2 dan 3 .

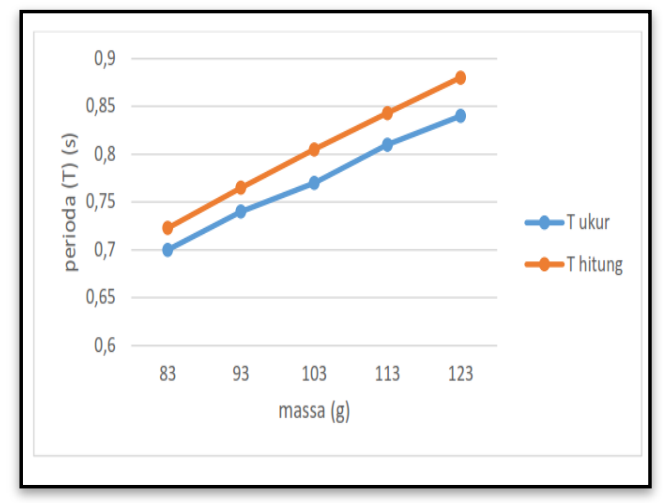

Gambar 1. Grafik hubungan antara massa beban terhadap perioda $(\mathrm{T})$ pengukuran dan perioda ( $\mathrm{T})$ perhitungan pada pegas tunggal

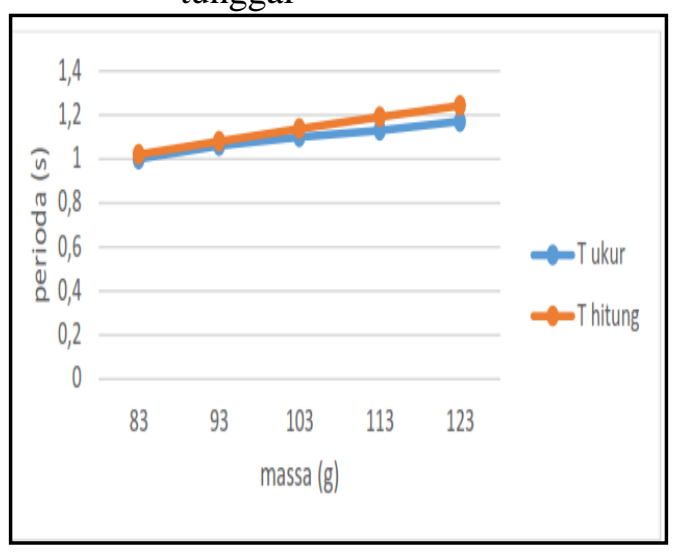

Gambar 2.Grafik Hubungan Antara Massa Beban terhadap Perioda (T) Pengukuran dan Perioda (T) Perhitungan pada Pegas yang Disusun Seri

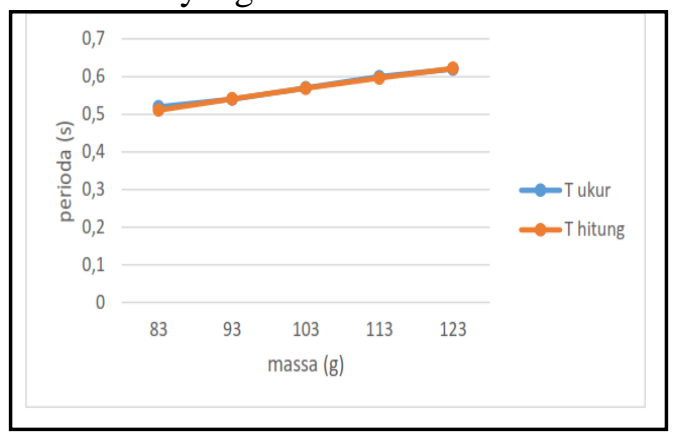

Gambar 3. Grafik Hubungan antara Massa Beban terhadap Perioda (T) Pengukuran dan Perioda (T) Perhitungan pada Pegas yang Disusun Paralel

Berdasarkan Gambar 1, 2 dan 3, terlihat bahwa selisish perioda ( $\mathrm{T}$ ) hasil perhitungan menggunakan teori dan perioda (T) hasil pengukuran oleh sistem tidak jauh berbeda.Berdasarkan analisis data, diketahui rata-rata ketepatan relatif pengukuran pada pegas tunggal adalah $96,16 \%$, ketepatan relatif alat pada pegas seri adalah $96,40 \%$ sedangkan pada susunan paralel 99,25\%.

Ketelitian sistem diketahui dengan cara melakukan pengukuran berulang, yakni pengukuran perioda osilasi pegas yang dilakukan sebanyak 10 kali pengukuran.Sama halnya dengan penentuan ketepatan alat, pada ketelitian juga dilakukan pada pegas tunggal, susunan pegas seri dan paralel. Untuk pegas tunggal didapatkan rata-rata ketelitian adalah $0,985 \%$, pegas seri 0,998 dan pegas paralel $0,981 \%$.

\section{Pembahasan}

Berdasarkan hasil analisis data, diketahui bahwa produk yang dikembangkan sudah valid, dengantingkat kevalidan yang diperoleh $>80 \%$. Hal ini sesuai dengan pendapat Riduwan (2009) yang menyatakan bahwa suatu produk dapat dikatakan valid apabila capaian responden lebih dari $60 \%$. Dengan demikian, maka produk yang dikembangkan dapat digunakan dalam pembelajaran. Hal ini sesuai dengan pendapat Asyar (2011) menyatakan bahwa validasi adalah proses permintaan persetujuan atau pengesahan terhadap kesesuaian produk dengan kebutuhan sehingga produk dinyatakan cocok dan layak digunakan dalam pembelajaran. Sugiyono (2010) yang menyatakan bahwa valid berarti instrument tersebut dapat digunakan untuk mengukur apa yang seharusnya diukur.

\section{KESIMPULAN}

Berdasarkan hasil penelitian diatas dapat disimpulkan bahwa LKPD fisika berpraktikum berorientasi model Problem BasedLearning berbantukan alat praktikum berbasis teknologi digitalmemiliki kriteria sangat valid. Terkait dengan alat praktikum GHS berteknologi digital yang dikembangkan memiliki ketepatan dan ketelitian yang sangat baik. Hal ini dapat diartikan bahwa LKPD fisika berpraktikum berorientasi model PBL berbantukan alat praktikum berbasis teknologi digital sangat valid dan dapat digunakan dalam pembelajaran.

\section{UCAPAN TERIMAKASIH}

Kemenristek Dikti melalui Hibah Tim Pascasarjana Program Studi Pendidikan Fisika FMIPA UNP 2016. Dr. Yulkifli, M.Si (Ketua Tim) Nomor Kontrak: 275/UN 35.2/PG/2016. 


\section{DAFTAR RUJUKAN}

Abidin,Yunus.2014.Desain Sistem Pembelajaran dalam Konteks Kurikulum 2013. Bandung: RedikaAditama, 90-91.

Asyhar, Rayandra. 2011. Kreatif Mengembangkan Media Pembelajaran. Jakarta: Gaung Persada Press. 48-49.

Barrow, H dan Tamblyn, R. 1980.ProblemBased Learning: An Approach to Medical Education. New York: Springer.76-77.

Majid, Abdul. 2014. Implementasi Kurikulum 2013: Kajian Teoritis dan Praktis. Bandung: Intereset Media. 126-127

Pascasarjana.2014. Panduan Penulisan Tesis dan Disertasi. Padang: Pascasarjana

Plomp, T. 2013.Educational and Training System Design.Enschede. Univercity of Twente: Netherlands: Part B illustrative cases. ISBN: 978-90-320-2335-8

Riduwan.2009.Belajar Mudah Penelitian untuk Guru, Karyawan dan Peneliti Pemula. Bandung: Alfabeta, 89-90.
Sudiati dan Asra. 2007. Metode Pembelajaran. Bandung: Wacana Prima.

Trianto. 2012. Model Pembelajaran Terpadu dalam Teori dan Praktek. Jakarta: Bumi Aksara

Sugiyono. 2009.MetodePenelitian Pendidikan PendekatanKuantitatif, Kualitatif,dan $R \& D$. Bandung:Alfabeta. 298-299

Yulkifli. 2011. Desain Sensor Getaran Frekuensi Rendah Berbasis Fluxgate. Jurnal. Vol 3 (2), 2011.

Yulkifli. 2016. Pengembangan Lembar Kerja Peserta Didik Berbasis Model Discovery Learning dan Alat Pratikum Gerak Melingkar Berbasis Teknologi Digital. Prosiding Konaspi VIII 2016.ISBN : 978-602-60240-0-8

Yulkifli. 2016. Pengembangan Teknologi Sensor Menjadi Alat-Alat Pratikum Fisika dalam Mendukung Implementasi Kurikulum 2013. Prosiding Semirata 2016 Bidang MIPA. ISBN: 978-60271798-1-3. 